\title{
Interaction Effect of Soilless Media and Organic Amendments for Eco-Friendly Root-Knot Nematode Management in Brinjal and Tomato Nursery
}

\author{
Ambuj Bhardwaj ${ }^{1}$, Abhishek Sharma2* (D), B.K. Goswami ${ }^{3}$ and Vijay Bhardwaj ${ }^{4}$ \\ ${ }^{1}$ Amity Institute of Organic Agriculture, Amity University, Noida - 201 313, Uttar Pradesh, India. \\ ${ }^{2}$ Amity Food and Agriculture Foundation, Amity University, Noida - 201 313, Uttar Pradesh, India. \\ ${ }^{3}$ Amity Centre for Biocontrol \& Plant Disease Management, Amity University, Noida - 201 313, Uttar Pradesh, \\ India. \\ ${ }^{4}$ Bioatlantis India Private Limited, Palam Colony, New Delhi - 110 045, India.
}

\begin{abstract}
Brinjal and tomato are the most important transplanted vegetable crops of the Solanaceae family. The successful cultivation of these crops is vital for meeting the nutritional dietary requirement of India's population and earning foreign exchange for the country by exporting vegetables to foreign countries. However, there are several abiotic and biotic impediments in the cultivation of these crops. Among biotic impediments, plant-parasitic nematodes have become one of the critical factor adversely affecting the cultivation of these vegetables. In general, Meloidogyne spp. (root-knot nematode) is the most common, widespread and economically damaging plant parasitic nematode species in tomato and brinjal crop. In addition to the damage caused by root - knot nematode, it stimulates the entry of soil-borne pathogens leading to development of the disease complex. The present study was undertaken to study the interaction effect of soil \& soilless growing media viz. cocopeat and vermicompost along with organic amendments i.e., Trichoderma, AM fungus, and Cabbage residue incorporated individually as well as in different combinations for eco-friendly root-knot nematode management in brinjal and tomato nursery. The results indicated that treatment C-8 (Cocopeat + Trichoderma + AM fungus + Cabbage residues) recorded the superior germination count, germination percentage, days to $50 \%$ germination, root length, shoot length, fresh weight, root weight, shoot weight and root: shoot ratio. It is pertinent to mention that the soilless media, along with various organic amendments, were found to be superior for all the root and shoot attributes as compared to the conventional soil media for growing healthy nursery of tomato and brinjal in root knot nematode infested geographies. Our findings provide an effective and sustainable method of growing healthy plant nursery in nematode infested regions.
\end{abstract}

Keywords: Solanaceae, Root - knot nematode, Cocopeat, Vermicompost, Nursery, Soilless media

*Correspondence: asharma5@amity.edu; +91-9911951615

(Received: October 01, 2020; accepted: February 18, 2021)

Citation: Bhardwaj A, Sharma A, Goswami BK, Bhardwaj V. Interaction Effect of Soilless Media and Organic Amendments for Eco-Friendly Root-Knot Nematode Management in Brinjal and Tomato Nursery. J Pure Appl Microbiol. 2021;15(1):356-367. doi:10.22207/JPAM.15.1.30

(C) The Author(s) 2021. Open Access. This article is distributed under the terms of the Creative Commons Attribution 4.0 International License which permits unrestricted use, sharing, distribution, and reproduction in any medium, provided you give appropriate credit to the original author(s) and the source, provide a link to the Creative Commons license, and indicate if changes were made. 


\section{INTRODUCTION}

Brinjal (Solanum melongena) and tomato (Solanum lycopersicum) are important transplanted vegetable crops of Solanaceae family grown in subtropics and tropics. In India, tomato is cultivated in 786 thousand hectares, with a total production of 19377 thousand metric tonnes. In contrast, brinjal is cultivated in 736 thousand hectares, with a total of 12826 thousand metric tonnes (Anonymous, 2018). The successful cultivation of these crops is vital for meeting out dietary nutritional requirement of the India's population as well as for earning foreign exchange by exporting vegetables to other countries. Plant parasitic nematodes are well known to cause adverse impact to cultivation and thereby causing financial losses to the farmers. The economic damage caused by nematodes worldwide is estimated to the tune of $\$ 157$ billion with projected yield loss upto $12.3 \%$ (Singh et al., 2015). The root-knot nematodes attacks on brinjal and tomato crops particularly in the nursery stage resulting in poor plant stand, reduced quality and low production (Manjunatha et al, 2017). Further, the root-knot nematode stimulates the entry of other soil borne pathogens leading to the development of disease complex. (Khan \& Sharma, 2020).

In view of the adverse impact of root-knot nematodes, it is important to manage the rootknot nematode infestation in the nursery itself. To overcome the limitations of soil production system (soil borne pests and other chemical and biological heterogeneity), soilless growing mediums are being preferred in nematode infested nurseries fields. FAO also refer that damage to transplanted vegetable by nematodes may be reduced using soilless media. The ideal characteristics of soilless media for successful nursery production include better water holding capacity, improved aeration, good drainage, and biological and chemical stability. Among several soilless media developed so far, cocopeat and vermicompost are prominent and readily available. Cocopeat is an agricultural by-product obtained after the extraction of fiber from the coconut husk (Abad et al, 2002). It is reported to have good porosity as it increases the availability of water in the potting mix. It is free from soil borne pathogens and is slightly acidic $\mathrm{pH}$ (5.7-6.5), which is ideal for plant growth. On the other side, vermicompost is a byproduct of the degradation of organic matter by earthworms and rich in major and minor nutrients having a positive effect on biochemical processes of plant (Edwards and Burrows, 1988). Use of biocontrol agents like Trichoderma species and arbuscular mycorrhizal (AM) fungi in the nurseries to contain the nematode infestation are also being employed by various researchers. Poveda et al, 2020 have stated Trichoderma, mycorrhizal and endophytic fungi are used as bio control agents against nematodes as resistance inducers. In addition, these biocontrol agents are able to reduce the damage caused by plant-parasitic nematodes and play a role in minimizing harm by providing higher nutrient and water uptake to the plant. Plant material from brassicaceae are promising for controlling plant parasitic nematodes. Plant materials from several species within the family Brassicaceae are considered a promising alternative practice for controlling plant-parasitic nematodes. Roubtsova et al, 2007 and Youssef and Lashein, 2013 \& Kwerepe and Labuschagne, 2003 have found broccoli and cabbage to be effective against root knot nematode. Vos et al (2012) has found AM fungus to be reducing the penetration of root knot nematodes through altered root exudation of their host.

In the current times the need of the hour is to make vegetable farming sustainable, by aiming at managing soil and plant health by ecofriendly methods while relying on the principles of integrated disease and pest management. The individual effect of each component of nematode management (soilless media/biocontrol agents/ organic amendment) in soil is well documented. However, the impact analysis of the integrated system has not been well-established in India. Consequently, the current study aims on emphasis on use of soilless media (Cocopeat, vermicompost) along with biocontrol agents (Trichoderma and AM fungi) and organic amendment (Cabbage residues) for growing healthy nursery of tomato and brinjal in the root-knot nematode infested fields.

\section{MATERIAL AND METHOD Location}

The present investigation was carried out in the department of Amity Institute of Organic Agriculture, Amity University, Noida during 2017- 
18 and 2018-19. The root knot nematode infested soil was collected from hotspots areas identified at Kurag village in Solan district of Himachal Pradesh, India. The collected soil samples were kept in refrigerator for use in plug-tray experiment.

\section{Materials}

Good quality seeds of commercial variety of tomato and brinjal crops were used in the experiment. Pusa Ruby variety of tomato and Pusa Purple long variety of brinjal was selected for carrying out the study in the experiments. The plug trays having 98 cell with each cell dimension as $1.50 \mathrm{~cm}$ depth and $1.3 \mathrm{~cm}$ top was used in the nursery experiments. The commercially available sterilized cocopeat and vermicompost media was purchased from the market for the experiment and soil infested with nematodes was collected from hotspots areas identified at Kurag villag (Latitude: 30.9500; Longitude: 77.5800) in Solan district of Himachal Pradesh, India. Trichoderma harzianum obtained from the market of the brand Tricho HR (T. harzianum 1\% WP Strain No. IIHR-TH-2 Accessions No. ITCC6888) and applied at 2g per kg of growing media. The commercially available AM fungus (Glomus fasciculatum) (Symbion VAM Plus) was applied at the rate of $10 \mathrm{~g}$ per $\mathrm{kg}$ of growing media. Cabbage residues was obtained from the local field of cabbage crop after harvesting of cabbage head and applied as $5 \mathrm{~g}$ per seedling at the time of transplanting.

\section{Identification of the Meloidogyne species}

Brinjal and tomato plants were randomly collected from the identified sick plot and were brought to the laboratory for morphological identification of the root-knot nematode species. The nematode were identified as Meloidogyne incognita using Eisenback et al (1981) pictorial key.

\section{Experimental detail}

The experiment was laid out in Factorial Completely Randomized Design with 8 treatments in factor one i.e. organic amendments viz. T-1 (Control), T-2 : (T. harzianum), T-3 (AM fungus), T-4 (Cabbage residue), T-5 (T. harzianum + AM fungus), T-6 (T. harzianum + Cabbage residue), T-7 (AM fungus + Cabbage residue) and T-8 ( $T$. harzianum + AM fungus + Cabbage residue) and three treatments in factor two i.e. soil and soil-less growing media viz. G-1 (Field Soil), G-2 (Vermicompost) and G-3 (Cocopeat) as shown in Table 1. The data on effect of organic amendments in nematode infested soil media viz., number of galls per 10 seedling and nematode population per $200 \mathrm{cc}$ soil was recorded. The data was recorded for different root and shoot parameters viz. germination, germination percentage, days to $50 \%$ germination, root length, shoot length, fresh weight, root weight, shoot weight and root: shoot ratio for brinjal and tomato seedlings in the nursery. The nematode infested soil collected from a nematode infested field used a growing media was used as a control treatment. The initial nematode population was estimated in nematode infested soil as 220 J2 / 200 cc soil by Cobb's Sieving and Decanting method.

\section{Statistical analysis}

Data were analyzed by one-way ANOVA followed by Duncan multiple range tests (DMRT) at P values of $<0.05$ using OPSTAT software available

Table 1. Details of different treatments with growing media and organic amendments for the experiment

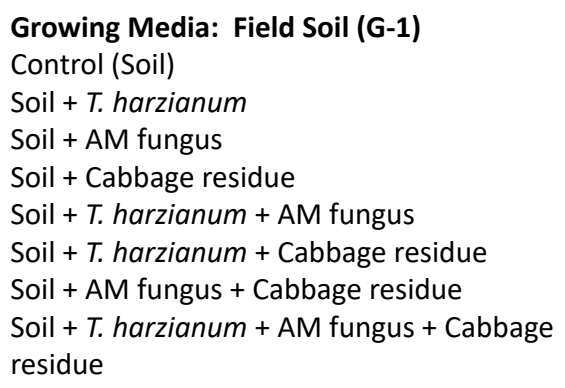

\section{Growing Media: Vermicompost (G-2)}

V-1 Control (Vermicompost)

V-2 Vermicompost $+T$. harzianum

V-3 Vermicompost + AM fungus

V-4 Vermicompost + Cabbage residue

V-5 Vermicompost + T. harzianum + AM fungus

V-6 Vermicompost $+T$. harzianum + Cabbage residue

V-7 Vermicompost + AM Fungus + Cabbage residue

V-8 Vermicompost + T. harzianum + AM fungus + Cabbage residue

\section{Growing Media: Cocopeat (G-3)}

C-1 Control (Cocopeat)

C-2 Cocopeat + T. harzianum

C-3 Cocopeat + AM fungus

C-4 Cocopeat + Cabbage residue

C-5 Cocopeat $+T$. harzianum + AM fungus

C-6 Cocopeat $+T$. harzianum + Cabbage residue

C-7 Cocopeat + AM fungus + Cabbage residue

C-8 Cocopeat + T. harzianum + AM fungus + Cabbage residue 


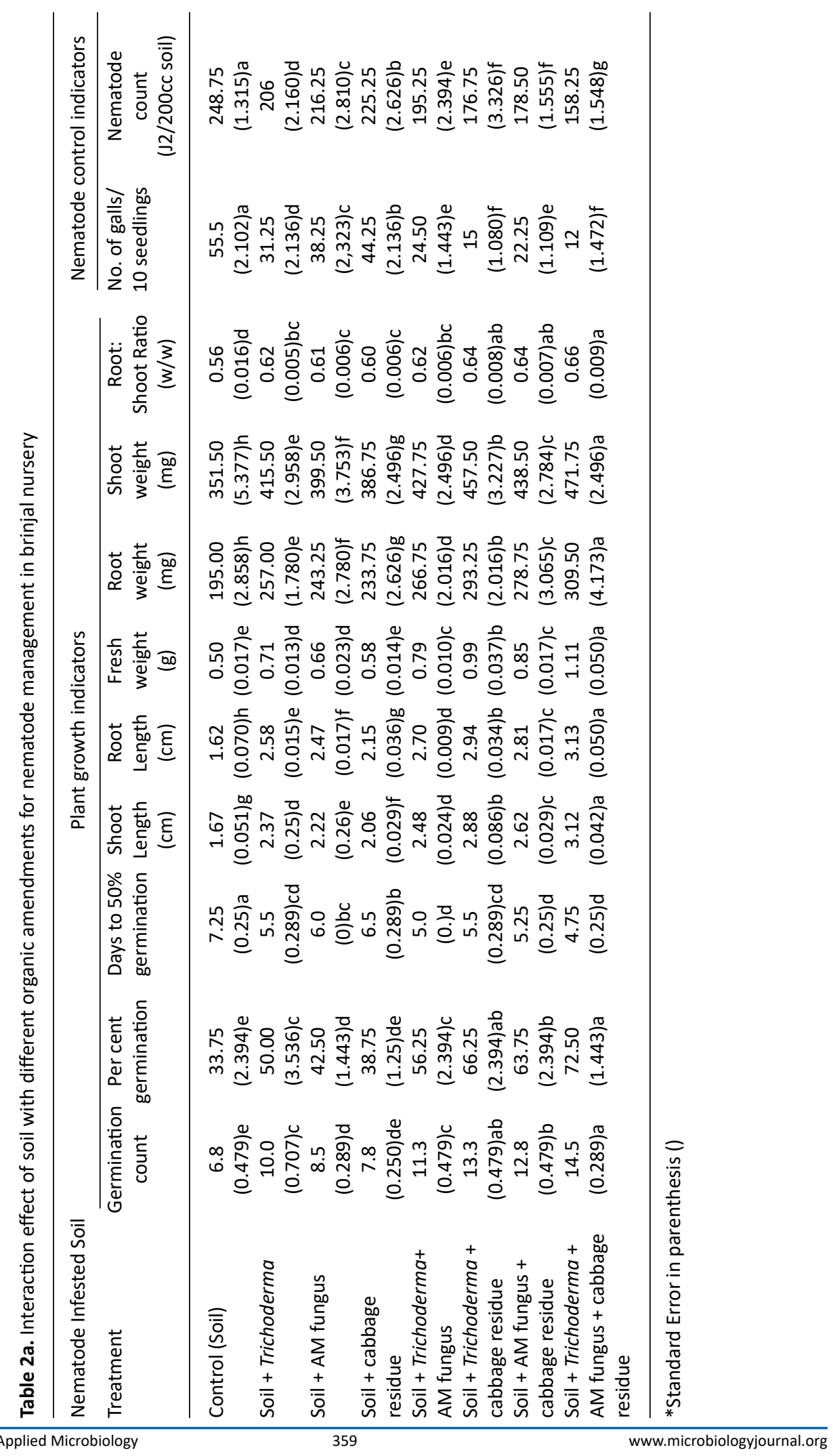




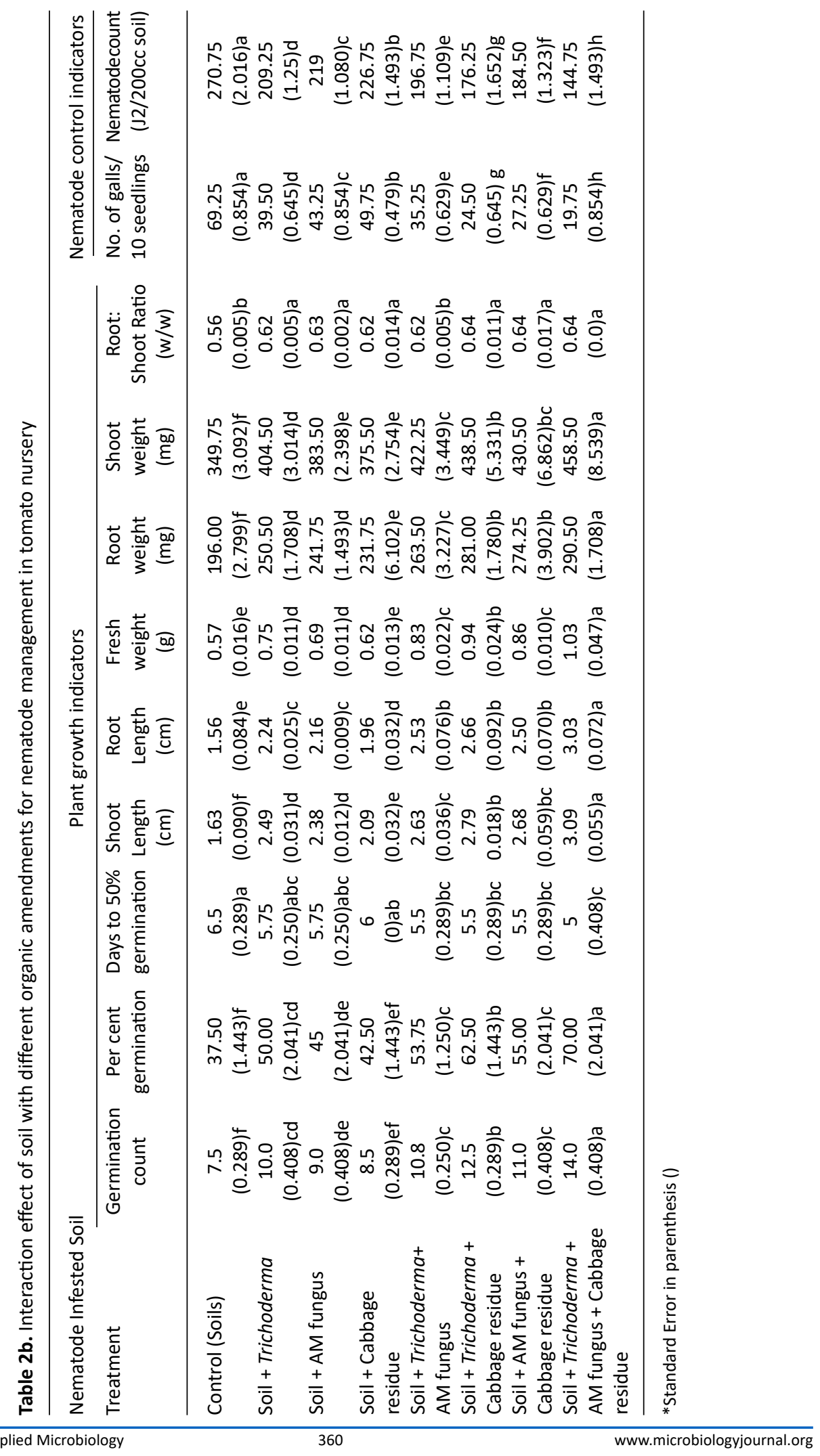


online at CCS HAU, Hisar website (www.hau.ernet. in).

\section{RESULTS}

Soil as Growing media and effect of plant growth parameters and nematode control

Data from the table $2 a$ and $2 b$ indicates that there was significant reduction in number of galls per 10 seedlings and reduction in nematode population in all the treatments as compared to the untreated check in both brinjal and tomato nursery experiments. The minimum number of gall per 10 seedlings was recorded in Soil + T. harzianum + AM fungus + Cabbage residue treatment followed by Soil $+T$. harzianum + Cabbage residue. It is also evident from the results of treatment having more than one organic amendment were superior in comparison to the treatments having single organic amendment. The incorporation of organic amendments had positive impact on root and shoot attributes. The observed data showed Soil + T. harzianum + AM fungus + Cabbage residue was the superior among all treatments followed by Soil $+T$. harzianum + Cabbage residue and Soil + AM fungus + Cabbage residue as compared to the untreated control for all the root and shoot attributes for both brinjal and tomato nursery seedlings.

Use of Soil less media and effect on plant growth parameters

A perusal of data presented in table $3 a$ and $3 \mathrm{~b}$ showed that the soilless growing media and organic amendments treatments and their interaction positively impacted the root and shoot parameters i.e. germination, germination percentage, days to $50 \%$ germination, root length, shoot length, fresh weight, root weight, shoot weight and root: shoot ratio in tomato and brinjal nursery, respectively. Amongst the two soil-less growing media, cocopeat recorded the superior germination count, germination percentage, days to $50 \%$ germination, root length, shoot length, fresh weight, root weight, shoot weight and root: shoot ratio in tomato and brinjal as compared to vermicompost as soil less growing media. Among the different organic amendments incorporated in the experiment along with the respective soil less media, Superior germination count, germination percentage, days to $50 \%$ germination, root length, shoot length, fresh weight, root weight, shoot weight and root: shoot ratio in tomato and brinjal nursery was observed in $\mathrm{C}-8$ followed by $C-6$ which is at par $(p<0.05)$ with $C-7, C-5$, and C-2. A similar trend was observed in interaction of vermicompost with organic amendments where treatment V-8 showed significantly $(p<0.05)$ higher germination, germination percentage, days to $50 \%$ germination, root length, shoot length, fresh weight, root weight, shoot weight and root: shoot ratio in tomato and brinjal nursery, followed by $V-6$ which was statistically $(p<0.05)$ at par with $\mathrm{V}-7$ and $\mathrm{V}-5$. Among the two soil-less growing media, the most inferior germination, germination percentage, days to $50 \%$ germination, root length, shoot length, fresh weight, root weight, shoot weight and root: shoot ratio in case of tomato and brinjal seedlings at the nursery stage was observed in control treatment ( $\mathrm{C}-1$ and $\mathrm{V}-1$ respectively) without any organic amendments. However, the interaction of different growing media and organic amendments showed positive effect on root and shoot parameters for tomato and brinjal seedlings in nursery as observed in treatment- Cocopeat+ T. harzianum + AM fungus + Cabbage residue, while poor effect was recorded in control with no amendments. All devised treatments proved significant over the control in increasing the healthy seed germination and root and shoot parameters of tomato and brinjal seedlings in the nursery.

\section{DISCUSSION}

The superior performance of brinjal and tomato seedling plants in cocopeat growing media can be attributed to its good aeration, high water holding capacity and its slightly high potassium content similar results about the positive effect of growing media on the growth characteristics of tomato and brinjal crops were reported by many researchers (Padem et al, 1994; Peyvast et al, 2007; Peyvast et al, 2010). Noguera et al (2000) also revealed from the study that the coconut waste turns out to be the best medium for growing horticultural crops under soilless conditions. When composted cocopeat was used as a growing media for tomato plants under soilless culture resulted in higher dry root weight (22\%), fruit number $(43 \%)$ and increase in total yield (64\%) as reported by Murphy (2000). Colla et al (2003) worked on soilless cultivation of cucumbers 


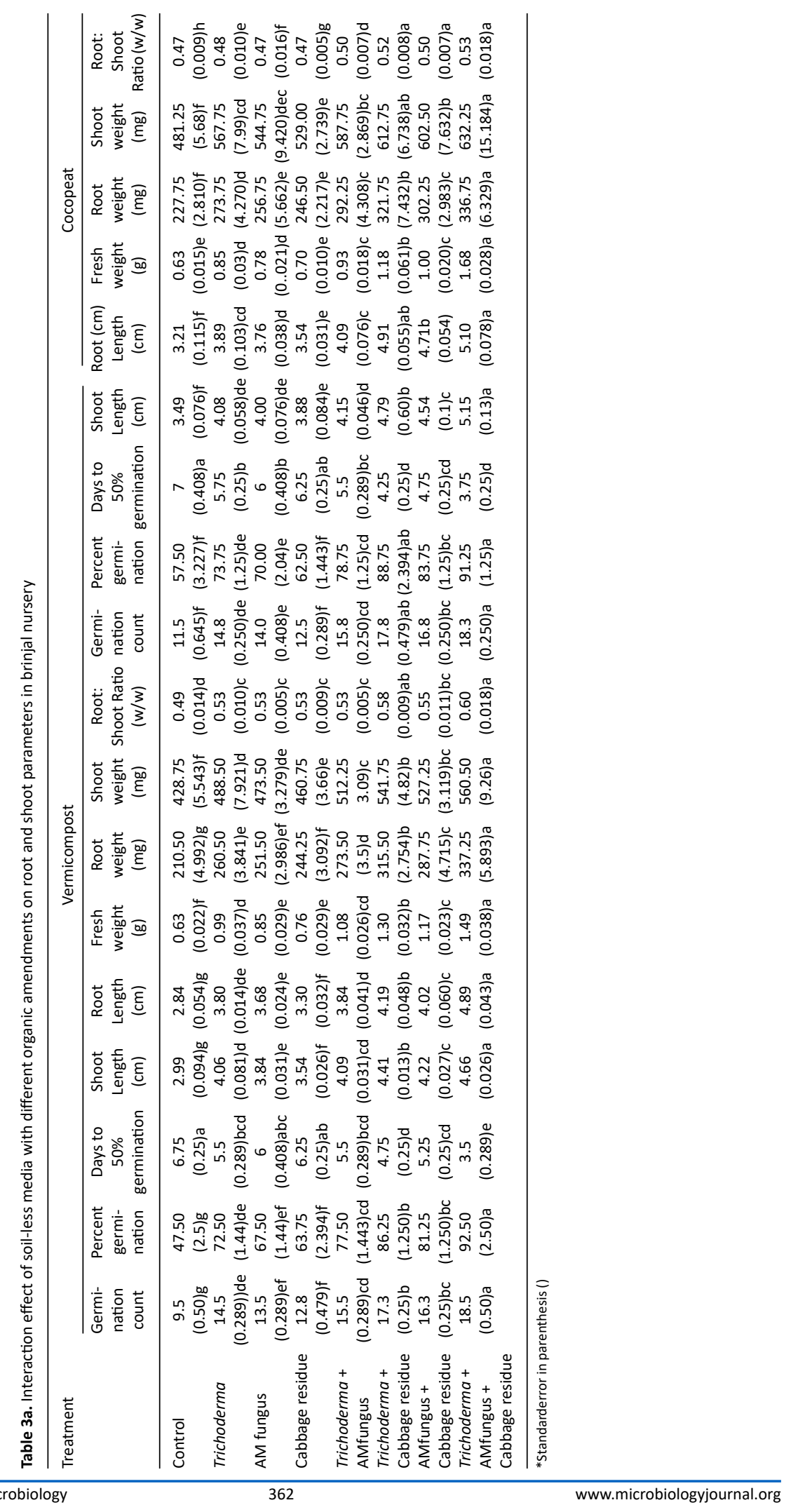




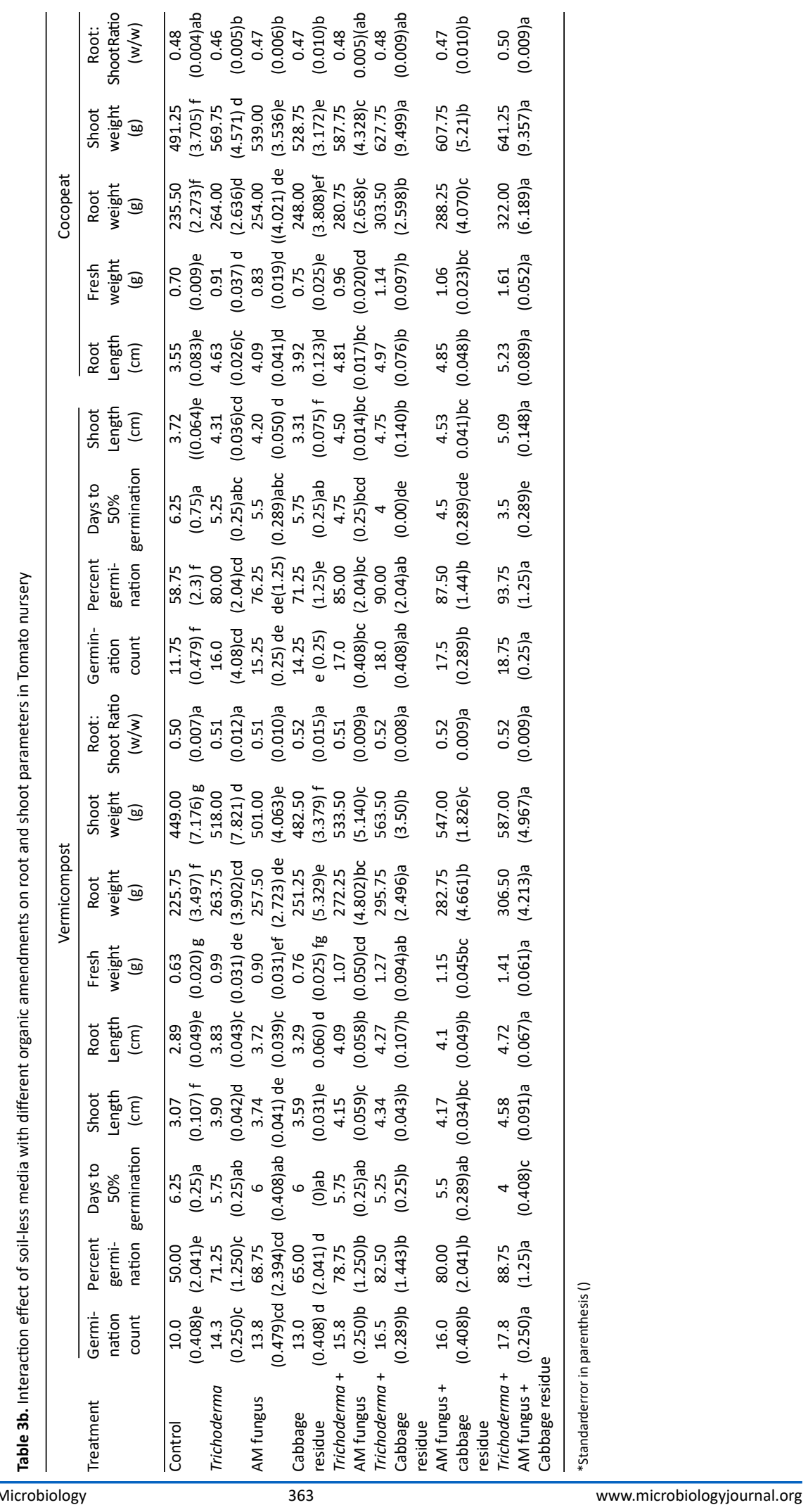


under coir pith and observed high yield, average number of fruits and average fruit weight. Carrijo et al (2004) observed that tomato crop yielded the heaviest fruits (128 g) when coconut fibre was used as a growing media. Cresswell (2002) suggested coconut coir dust as an alternative in soilless culture due to its less acidic nature, high porosity and good water holding capacity, better capillary wetting and physical stability. When coco peat was used as the growing medium, tomato plants produced higher vegetative growth and yield per plant as reported by Reshma and Sarath (2017). Similar to cocopeat, use of vermicompost also have a positive impact on growth parameters. Edward (1988) reported that vermicompost could promote early and vigorous growth of seedlings. Vermicompost's has been found to be effective in enhancement of root and shoot growth parameters (Grappelli et al.,1985; Atiyeh et al 1999; Bhardwaj R L, 2011).

Arbuscular mychorrhizal fungi (AMF) plays an important role in promoting plant growth attributes and nematode management. Campos M.A.D.S., 2020 reported AMF positive effect on growth of a plant infected with Meloidogyne. Valeria (2015) reported that AM fungus role is known to have positive effect on germination in radish Bhuiyan, MAH et al (2016) reported biomass yield, seedling height and nutrient uptake by tomato seedlings increased greatly with the use of AM inoculum

Dababat et al (2006) studied use of Trichoderma harzianum and Trichoderma viride in biological control of Meloidogyne incognita in tomato and found that all tested isolates were effective in causing nematode mortality. Asaduzzaman et al (2010) reported usefulness of Trichoderma spp in enhancing the germination of chilli seeds as well as reduction to delayed germination. Heidari and Olia (2016) reported use of Trichoderma harzianum along with vermicompost controlled root Knot nematodes along with increasing plant growth in tomato. Similar to AM fungus, Trichoderma has also reported to have positive impact of shoot length. Ban, Gwendolyn et al (2018) reported in their study in tomato and bean that on an average, Trichoderma inoculation increased the root and shoot length, and the fresh weight up to 26.4, 9.6 and $18.8 \%$, respectively over the control. Tanwar et al (2013) demonstrated that application of $T$. viride alone or in combination with other growth promoting microbes (AM fungi and $P$. fluorescens) proved to be a promising factor for improved growth performance, including root length.

Anita (2012) reported that ethanol extracts of cabbage, cauliflower, radish and Chinese cabbage leaves reduced population of $M$. hapla and improved celery plant growth criteria of which, radish leaf residue was the most effective resulting in $60.6 \%$ reduction in nematode population in soil and $41.9 \%$ increase in celery green leaves and stalk yield. El-Sherbiny and Awd Allah (2014) reported similar trend as they observed that air dried powder of some plants of which cauliflower (belonging to cabbage plants) when added as pre-planting reduced $M$. incognita on tomato plants and improved plant growth criteria.

Roubtsova et al (2007) stated that bio fumigants to be effective against nematodes require uniform distribution through the soil profile as the target nematodes exists. El-Nagdi et al (2019) reported that when mashed leaves of cabbage and kohlrabi belonging to family Brassicaceae were added 10 days before sowing resulted in decrease in root knot nematode $M$. incognita infection in cowpea plant, thereby improving overall plant growth.

\section{CONCLUSION}

The present study established the interrelationship between principle of exclusion, integrated pest management and waste management to achieve sustainable plant protection. The finding revealed that use of soil-less media along with organic amendments provided health nursery seedling with superior root and shoot attributes as compared to using soil as growing medium for raising nursery in nematode infested geographies. However, when soil was used as growing media, incorporation of organic amendments was able to reduce the nematode population and root galling in the nursery plants along with better growth parameters as compared to untreated check. The study demonstrates growing healthy tomato and brinjal nursery by use of soilless medium (cocopeat or vermicompost) along with incorporating of $T$. harzianum, AM fungus and Cabbage residues. Our 
study will not only provide impetus to sustainable agriculture but would also help the farmers and society in maintaining the quality of soil health and environment benefitting from use of ecofriendly pest management methods.

\section{ACKNOWLEDGMENTS}

We would like to express heartfelt thanks to the Founder President, Amity University Hon'ble Dr. Ashok Kumar Chauhan for the infrastructural support.

\section{CONFLICT OF INTEREST}

The authors declare that there is no conflict of interest.

\section{AUTHORS' CONTRIBUTION}

All authors listed have made a substantial, direct and intellectual contribution to the work, and approved it for publication.

\section{FUNDING}

None.

\section{DATA AVAILABILITY}

All datasets generated or analysed during this study are included in the manuscript.

\section{ETHICS STATEMENT}

This article does not contain any studies with human participants or animals performed by any of the authors.

\section{REFERENCES}

1. Abad M, Noguere P, Puchades R, Maquieira A, Noguera V. Physio-chemical and chemical properties of some coconut dusts for use as a peat substitute for containerized ornamental plants. Bioresource Technol. 2002;82(3):241-245. doi: 10.1016/S09608524(01)00189-4

2. Anita B. Cabbage vegetable leaf wastes as biofumigants for the management of root knot nematode (Meloidogyne hapla Chitwood) in celery (Apium graveolens L.). Journal of Biopesticides. 2012;5(Supple):111-114.

3. Anonymous. Agricultural Statistics at a Glance 2018, Ministry of Agriculture \& Farmers Welfare Department of Agriculture, Cooperation \& Farmers Welfare Directorate of Economics and Statistics. 2018.

4. Ban $G$ et al. The effect of Trichoderma on the growth and development of tomato and bean under greenhouse and field conditions. Annals of Tropical Research. 2018: doi: 10.32945/atr4013.2018

5. Bhardwaj RL. Effect of growing media on seed germination and seedling growth of papaya cv. 'Red lady'. African Journal of Plant Science. 2014;8(4):178184. doi: 10.5897/AJPS11.265

6. Bhuiyan MAH et al. Effect of Arbuscular Mycorrhizal Inoculum Rate on Tomato (Lycopersicum esculenta L.) Seedlings. Bangladesh Journal of Microbiology. 2016;29. 104-108. doi: 10.3329/bjm.v29i2.28444

7. Bonfante $P$, Genre A. Mechanisms underlying beneficial plant-fungus interactions in mycorrhizal symbiosis. Nat Commun. 2010;1:48. doi: 10.1038/ncomms1046

8. Carrijo OA, Vidal MC, Reis NV, Souza RBD, Makishima N. Tomato crop production under different substrates and greenhouse models. Hortic Brasileira. 2004;22(1):5-9. doi: 10.1590/S0102-05362004000100001

9. Vos C, Claerhout S, Mkandawire R, Panis B, Waele $D D$, Elsen A. Arbuscular mycorrhizal fungi reduce root-knot nematode penetration through altered root exudation of their host. Plant Soil. 2012;354:335-345. doi: 10.1007/s11104-011-1070-x

10. Colla G, Saccardo F, Rea E, Pierandrei F, Salerno A. Effects of substrates on yield, quality and mineral composition of soilless-grown cucumbers. In: Proceedings of the VI International Symposium on Protected Cultivation in Mild Winter Climate: Product and Process Innovation. 2003:205-209. doi: 10.17660/ ActaHortic.2003.614.29

11. Cresswell G. Coir dust a proven alternative to peat. In: Proceedings of the Australian Potting Mix Manufacturers Conference, Sydney. 2002:1-5.

12. Dababat AA, Sikora RA, Hauschild R. Use of Trichoderma harzianum and Trichoderma viride for the biological control of Meloidogyne incognita on tomato. Commun Agric Appl Biol Sci. 2006;71(3 Pt B):953-61. PMID: 17390844.

13. Edwards CA, Burrows I. Potential of earthworm composts as plant growth media in Neuhauser, C.A. In.: Earthworms in environmental and waste management. SPB Academic Publishing, The Hague, the Netherlands. 1988:211- 220.

14. Eisenback JD, Hirschmann H, Sasser JN, Triantaphyllou AC. A guide to the four most common species of root knot nematodes (Meloidogyne species), with pictorial key. Raleigh: North Carolina State University Graphics. 1981.

15. El-Nagdi WMA, Youssef MMA. Brassica vegetable leaf residues as promising biofumigants for the control of root knot nematode, Meloidogyne incognita infecting cowpea. Agricultural Engineering International: CIGR Journal. 2019;21(1):134-139.

16. El-Sherbiny AA, Awd Allah SFA. Management of the root-knot nematode, Meloidogyne incognita on tomato plants by pre-planting soil biofumigation with harvesting residues of some winter crops and waste residues of oyster mushroom cultivation under field condition. Egyptian Journal of Agronematology. 2014;13(1):189-202. doi: 10.21608/ejaj.2014.63695

17. Gowen SR. Alternate strategies for nematode control towards sustainable agriculture. Food and Agriculture Organization. http://www.fao.org/

18. Grappelli A, Tomati U, Galli E. Earthworm Casting in Plant Propagation. Horticultural Science. 1985;20:874876. 
19. Gutowski V. "The effect of mycorrhizae on seed germination, development, and reproductive yield of Rapid Gro Radish," ESSAI. 2015;13:18.

20. Halberendt JM. Allelopathy in the management of plant-parasitic nematodes. Journal of Nematology. 1996;28(1):8-14.

21. Harman GE, Howell CR, Viterbo A, Chet I, Lorito M. Trichoderma species opportunistic, avirulent plant symbionts. Nat Rev Microbiol. 2004;2:43-56. doi: 10.1038/nrmicro797

22. Heidari F, Olia M. Biological control of root-knot nematode, Meloidogyne javanica, using vermicompost and fungus Trichoderma harzianum on tomato. Iran J Plant Pathol. 2016;52(1):109-124.

23. Khan MR, Sharma RK. Fusarium-nematode wilt disease complexes, etiology and mechanism of development. Indian Phytopathology. 2020;73:615-628. doi: 10.1007/s42360-020-00240-z

24. Kirkegaard JA, Sarwar M. Biofumigation potential of brassicas. I. Variation in glucosinolate profiles of diverse field-grown brassicas. Plant and Soil. 1998;201(1):71-89. doi: 10.1023/A:1004364713152

25. Kwerepe BC, Labuschagne N. Biofumigation and solarization as integrated pest management (IPM) components for the control of root knot nematode (Meloidogyne incognita (Kofoid \& White) Chitwoodi) on Bambara Groundnut (Vigna subterranea (L.) Verdc). UNISWA Journal of Agriculture. 2003;11:56-62. doi: 10.4314/uniswa.v11i1.4628

26. Asaduzzaman M, Alam MJ, Islam MM. Effect of Trichoderma on seed germination and seedling parameters of chilli. J Sci Foundation. 2010;8(1\&2):141150. doi: 10.3329/jsf.v8i1-2.14637

27. Gowda MT, Rai AB, Singh B. Root Knot Nematode: A Threat to Vegetable Production and its Management. IIVR Technical Bulletin No. 76, IIVR, Varanasi. 2017:32.

28. Campos MAdS. Bioprotection by arbuscular mycorrhizal fungi in plants infected with Meloidogyne nematodes: A sustainable alternative. Crop Protection. 2020;135:105203. doi: 10.1016/j.cropro.2020.105203

29. Matthiessen JN, Kirkegaard JA. Biofumigation and biodegradation: opportunity and challenge in soil-borne pest and disease management. Crit Rev Plant Sci. 2006;25(3):235-265. doi: 10.1080/07352680600611543

30. Miller MA, Jastrow JD (1994). Vesicular arbuscular mycorrhizae and biogeochemical cycling. In Rahman, M. K., S. M. Kabir, G. M. Mohsin and M. DidarulAlam (2006). Interaction of Arbuscular Mycorrhizal Fungus Glomus mosseae and Phosphorus on Growth and Nutrient Uptake of Maize Plants Grown Under Different Soil Conditions. Bangladesh J. Bot. 35(1):1-7.

31. Motisi N, Dore T, Lucas P, Montfort F. Dealing with the variability in biofumigation efficacy through an epidemiological framework. Soil Biol Biochem. 2010;42(12):2044-2057. doi: 10.1016/j. soilbio.2010.08.016

32. Naseby DC, Pascual JA, Lynch JM. Effect of biocontrol strains of Trichoderma on plant growth, Pythium ultimum populations, soil microbial communities and soil enzyme activities. J App/ Microbiol. 2000;88(1):161169. doi: 10.1046/j.1365-2672.2000.00939.x
33. Noguera P, Abad M, Noguera V, Puchades R, Maquieira $A$. Coconut coir waste, a new and viable ecologicallyfriendly peat substitute. In: Herregods, M., Boxus, P., Baets, W., and Jager, A. (eds), Proceedings of the XXV International Horticultural Congress. Part 7. Quality of horticultural products: starting material, auxiliary products, quality control, Brussels, Belgium. 2000:279-286. doi: 10.17660/ActaHortic.2000.517.34

34. Padem H, Alan R. The effect of some substrates on yield and chemical composition of pepper under greenhouse conditions. Acta Hortic. 1994;366: 445452. doi: 10.17660/ActaHortic.1994.366.55

35. Peyvast GH, Noorizadeh M, Hamidoghli J, RamezaniKharazi P. Effect of four different substrates on growth, yield and some fruit quality parameters of cucumber in bag culture. Acta Hortic. 2007;742:175-182. doi: 10.17660/ActaHortic.2007.742.23

36. Peyvast GH, Olfati JA, Kharazi PR, Roudsari ON. Effect of substrate on greenhouse cucumber production in soilless culture. Acta Hortic. 2010;871:429-436. doi: 10.17660/ActaHortic.2010.871.59

37. Poveda J, Urias PA, Escobar C. Biological Control of Plant-Parasitic Nematodes by Filamentous Fungi Inducers of Resistance: Trichoderma, Mycorrhizal and Endophytic Fungi. Front Microbiol. 2020;11:992. doi: 10.3389/fmicb.2020.00992

38. Rahbarian P, Sardoei AS. Effect of waste of palm trees and sand and perlite mixed with some growth indices of Ficus benjamina. International Journal of Advanced Biological and Biomedical Research. 2014;2: 573-578.

39. Rai MK. Handbook of Microbial Biofertilizers. The Haworth Press, Inc. 2006. doi: 10.1201/9781482277760 Reshma T, Sarath PS. Standardization of Growing Media for the Hydroponic Cultivation of Tomato. Int J Curr Microbiol App Sci. 2017;6(7):626-631. doi: 10.20546/ ijcmas.2017.607.076

41. Roubtsova T, Lopez-Perez A, Edwards S, Ploeg A. Effect of Broccoli (Brassica oleracea) tissue, incorporated at different depths in a soil column on Meloidogyne incognita. Journal of Nematology. 2007;39(2):111-117.

42. Singh S, Singh B, Singh AP. Nematodes: a threat to sustainability of agriculture. Procedia Environ Sci. 2015;29:215-216. doi: 10.1016/j.proenv.2015.07.270

43. Tanwar A, et al. Interactive Effect of AM Fungi with Trichoderma viride and Pseudomonas fluorescens on Growth and Yield of Broccoli. Plant Protect Sci. 2013;49:137-145. doi: 10.17221/54/2012-PPS

44. Theunissen J, Ndakidemi PA, Laubscheres CP. Potential of vermicompost produced from plant waste on the growth and nutrient status in vegetable production. International Journal of the Physical Sciences. 2010;5:1964-1973.

45. Tuzel Y, Oztekin GB, Gul A. Recent developments in protected cultivation in Turkey. 2nd coordinating meeting of the regional FAO working group on Greenhouse Crop Production Antalya. 2008:75-86.

46. Wallach, Rony. Physical Characteristics of Soilless Media. Soilless Culture 2008:41-116. doi: 10.1016/ B978-044452975-6.50005-8

47. Wilson SB, Stofella PJ, Graetz DA. Use of compost as a media amendment for containerized production of two subtropical perennials. Journal of Environmental 
Bhardwaj et al. | J Pure Appl Microbiol | 15(1):356-367 | March 2021 | https://doi.org/10.22207/JPAM.15.1.30

Horticulture. 2001;19(1):37-42. doi: 10.24266/07382898-19.1.37

48. Youssef MMA. Biofumigation as a promising tool for managing plant parasitic nematodes. A review. Scientia Agriculturae. 2015;10(3):115-118. doi: 10.15192/PSCP. SA.2015.10.3.115-118
49.

Youssef MMA, Lashein AMS. Effect of cabbage (Brassica oleracea) leaf residue as a biofumigant on root knot nematode, Meloidogyne incognita infecting tomato. J Plant Prot Res. 2013;53(3):271-274. doi: 10.2478/ jppr-2013-0040 